Research Article

\title{
Scattered organization of the histone multigene family and transposable elements in Synbranchus
}

\author{
Ricardo Utsunomia, José Carlos Pansonato-Alves, Priscilla Cardim Scacchetti, \\ Claudio Oliveira and Fausto Foresti \\ Departamento de Morfologia, Instituto de Biociências, \\ Universidade Estadual Paulista “Júlio de Mesquita Filho”, Botucatu, SP, Brazil.
}

\begin{abstract}
The fish species Synbranchus marmoratus is widely distributed throughout the Neotropical region and exhibits a significant karyotype differentiation. However, data concerning the organization and location of the repetitive DNA sequences in the genomes of these karyomorphs are still lacking. In this study we made a physical mapping of the H3 and $\mathrm{H} 4$ histone multigene family and the transposable elements Rex 1 and Rex3 in the genome of three known S. marmoratus karyomorphs. The results indicated that both histone sequences seem to be linked with one another and are scattered all over the chromosomes of the complement, with a little compartmentalization in one acrocentric pair, which is different from observations in other fish groups. Likewise, the transposable elements Rex1 and Rex3 were also dispersed throughout the genome as small clusters. The data also showed that the histone sites are organized in a differentiated manner in the genomes of S. marmoratus, while the transposable elements Rex 1 and Rex 3 do not seem to be compartmentalized in this group.
\end{abstract}

Key words: Synbranchidae, FISH, histone, retrotransposon.

Received: August 1, 2013; Accepted: October 3, 2013.

\section{Introduction}

The genomes of eukaryotic organisms are characterized by a large number of repetitive DNA segments. These sequences are identifiable by a high variability in their nucleotide composition, number of copies, function, distribution and organization in the genome (Wagner et al., 1993; Charlesworth et al., 1994). Generally, these sequences may be classified as coding sequences, represented by ribosomal and histone multigene families, and noncoding sequences, repeated in tandem or dispersed throughout the genome (Sumner, 2003; Nagoda et al., 2005)

The repetitive nature of these sequences makes them ideal for the development of probes for use in fluorescence in situ hybridization (FISH). Studies related to the organization and physical mapping of these types of sequences have enabled a better characterization of the biodiversity and karyoevolution of the ichthyofauna (Vicari et al., 2010). Furthermore, these data have also helped advancing in the knowledge of the organization, diversification, evolution and possible role of repetitive DNA sequences in the genome of vertebrates (Haff et al., 1993; Martins and Galetti Jr, 1999; Gursel et al., 2003). However, the vast majority of

Send correspondence to Ricardo Utsunomia. Departamento de Morfologia, Instituto de Biociências, Universidade Estadual Paulista "Júlio de Mesquita Filho", Distrito de Rubião Junior, s/n, 18618970 Botucatu, SP, Brazil. E-mail: utricardo@ibb.unesp.br. mapping studies carried out on Neotropical fishes were focused on the location of ribosomal sites, and there is still very little information regarding other types of sequences, such as histone genes and transposable elements (TEs). Even though studies on physical mapping of histone genes and TEs are few, interesting features about those sequences have been revealed, such as association with other repetitive families (Cioffi et al., 2010; Hashimoto et al., 2011, 2013; LimaFilho et al., 2012), distinct modes of organization (Valente et al., 2011; Ferreira et al., 2011a), and influences on karyotype diversification (Pansonato-Alves et al., 2013a).

Although known as a single taxonomic entity, $S$. marmoratus (Synbranchiformes, Synbranchidae) displays considerable cytogenetic diversity. As a result, there are distinct karyotype variants (Foresti et al., 1992; Melilo et al., 1996; Sánchez and Fenocchio, 1996; Torres et al., 2005), resulting in five well-differentiated main karyomorphs (unpublished data). Individuals in karyomorph groups $\mathrm{A}$ and $\mathrm{B}$ have chromosome number $2 \mathrm{n}=42$. In addition, a pericentric inversion in a submetacentric chromosome of karyomorph A is related to the origin of karyomorph B. In contrast, analyses of chromosome rearrangements cannot definitively explain the origins of karyomorphs C $(2 n=46), D$ and $E(2 n=46)$, because the events responsible for their diploid chromosome numbers seem to originate from undependable and bidirectional events (unpublished data). This study describes the cyto- 
genetic mapping of the histone sequences $\mathrm{H} 3$ and $\mathrm{H} 4$ and of the transposable elements Rex 1 and Rex3 in samples from three S. marmoratus karyomorphs. The purpose of this study was to investigate the distribution patterns of each element in this group.

\section{Material and Methods}

\section{Samples}

Mitotic chromosomes were obtained from kidney tissue, as described by Foresti et al. (1981), from specimens of karyomorphs A, B and E, collected at different Brazilian locations, as specified in Table 1 and Figure 1. All samples were collected in accordance with the Brazilian Environmental Law (Collection permission MMA/IBAMA/SISBIO - Nr. 3245), and the procedures for fish collection, maintenance and analysis were performed in compliance with the Brazilian College of Animal Experimentation (COBEA) and approved (protocol Nr. 503) by the Bioscience Institute/UNESP Ethics Committee on Use of Animals (CEUA). After the analyses, the fishes were fixed in 10\% formalin, conserved in $70 \%$ ethanol and deposited in the fish collection of the Fish Biology and Genetics Laboratory (Laboratório de Biologia e Genética de Peixes) - UNESP, Botucatu, São Paulo, Brazil. Voucher information is also presented in Table 1.

\section{Isolation of repetitive DNA sequences and FISH}

Genomic DNA of S. marmoratus (karyomorph A) was extracted using the Wizard Genomic DNA Purification Kit (Promega). Partial sequences of the histone genes H3 and $\mathrm{H} 4$ and the retrotransposable elements Rex 1 and Rex3 were obtained by polymerase chain reaction (PCR) using previously described primers (White et al., 1990; Colgan et al., 1998; Volff et al., 1999, 2000; Pineau et al., 2005). During the secondary PCR assay, the $\mathrm{H} 3$ and $\mathrm{H} 4$ histone sequences were labeled with biotin-16-dUTP (Roche), and the Rex1 and Rex3 TEs and 18S rDNA with digoxigenin-11-dUTP (Roche), by incorporating these modified nucleotides.

FISH was performed using the method described by Pinkel et al. (1986). Slides were incubated with RNase

Table 1 - Synbranchus marmoratus specimens analyzed.

\begin{tabular}{|c|c|c|c|c|c|}
\hline Locality & River Basin & Karyomorph (n) & Map & Coordinates & LBP \\
\hline Bataguassu - MS & Paraná & A (3) & 2 & S $21^{\circ} 38^{\prime} 49^{\prime \prime}-\mathrm{W} 52^{\circ} 17^{\prime} 52^{\prime \prime}$ & 11355 \\
\hline Guaíra - PR & Paraná & $\mathrm{B}(20)$ & 3 & 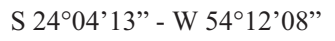 & 11364 \\
\hline Igaraçu do Tietê - SP & Tietê & $\mathrm{E}(2)$ & 1 & S $22^{\circ} 34^{\prime} 43^{\prime \prime}-\mathrm{W} 48^{\circ} 27^{\prime} 48^{\prime \prime}$ & 17519 \\
\hline
\end{tabular}

$\mathrm{n}=$ number of samples; LBP = deposit number in the fish collection of the Fish Biology and Genetics Laboratory (Instituto de Biociências de Botucatu, UNESP).

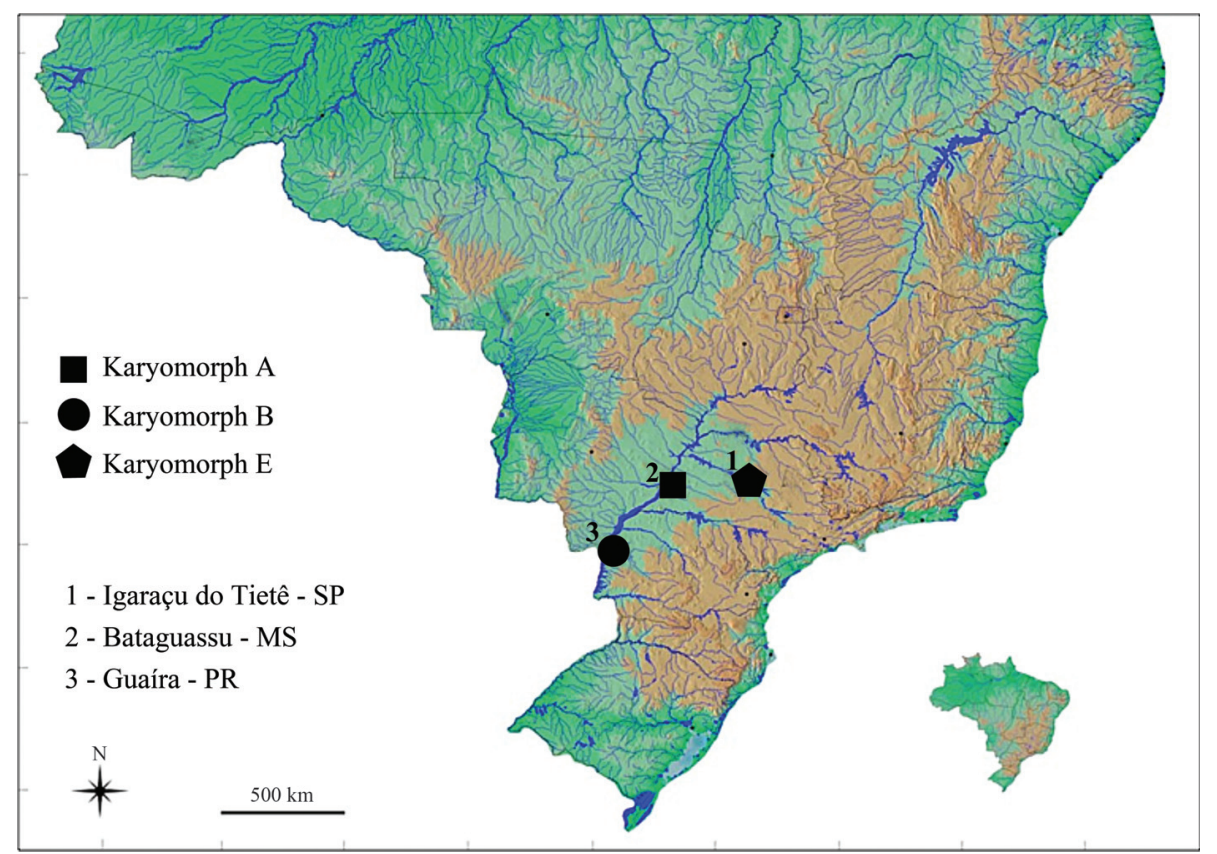

Figure 1 - Map showing the $S$. marmoratus specimen collection sites. The numbers indicate the sample locality, while symbols represent the karyomorphs found in each locality. 
$(50 \mu \mathrm{g} / \mathrm{mL})$ for $1 \mathrm{~h}$ at $37^{\circ} \mathrm{C}$. Then, the chromosomal DNA was denatured in $70 \%$ formamide in $2 \mathrm{x} \mathrm{SSC}$ for $5 \mathrm{~min}$ at $70{ }^{\circ} \mathrm{C}$. For each slide, $30 \mu \mathrm{L}$ of hybridization solution (containing $200 \mathrm{ng}$ of each labeled probe, $50 \%$ formamide, $2 \mathrm{x}$ SSC and $10 \%$ dextran sulphate) were denatured for $10 \mathrm{~min}$ at $95{ }^{\circ} \mathrm{C}$, dropped onto the slides and hybridized overnight at $37{ }^{\circ} \mathrm{C}$ in a $2 \mathrm{x} \mathrm{SSC}$ moist chamber. After hybridization, the slides were washed in a $0.2 \mathrm{x}$ SSC solution with $15 \%$ formamide for $20 \mathrm{~min}$ at $42^{\circ} \mathrm{C}$, followed by a second wash in $0.1 \mathrm{x} \mathrm{SSC}$ for $15 \mathrm{~min}$ at $60^{\circ} \mathrm{C}$, and a final wash in $4 \mathrm{x} \mathrm{SSC}$ with $0.5 \%$ Tween for $10 \mathrm{~min}$ at room temperature. Probe detection was carried out with Avidin-FITC (Sigma) or anti-digoxigenin-rhodamine (Roche), the chromosomes were counterstained with DAPI (4',6-diamidino-2-phenylindole, Vector Laboratories), and the FISH images were captured by an optical photomicroscope (Olympus, BX61) with the Image Pro Plus 6.0 software (Media Cybernetics).

\section{Results}

\section{Cytogenetic analysis}

All repetitive probes used here were clearly visualized in the mitotic chromosomes. Both $\mathrm{H} 3$ and $\mathrm{H} 4$ histone sequences appeared to be clustered together and were dis- tributed in a general pattern with dispersed signals on all chromosomes. Additionally, both sequences were accumulated in one acrocentric pair (Figure 2a-f).

Since the histone sites mapped until now in fishes were found in conspicuous blocks, we used the doubleFISH technique (18S rDNA + H3 histone sequences), in order to compare the hybridization patterns of both probes and check the veracity of the dispersed signal pattern of the histone sequences. Double-FISH confirmed that, as expected, in Synbranchus the histone sites are dispersed throughout the genome, while the $18 \mathrm{~S}$ rDNA sites are only present in one big cluster (Figure 3a-d).

Similarly, the Rex 1 and Rex3 TEs are arranged in small clusters that are also dispersed throughout the genome (Figure $4 \mathrm{a}-\mathrm{f}$ ). However, in the individuals belonging to karyomorph A collected at Bataguassu, only the Rex3 elements demonstrated significant accumulation in chromosome pair 3 (Figure 4d).

\section{Discussion}

Histone genes constitute a complex multigene family and may show variations in copy number and organization within the genome (Kedes, 1979). Thus, some species may present up to a few thousand histone gene copies, usually
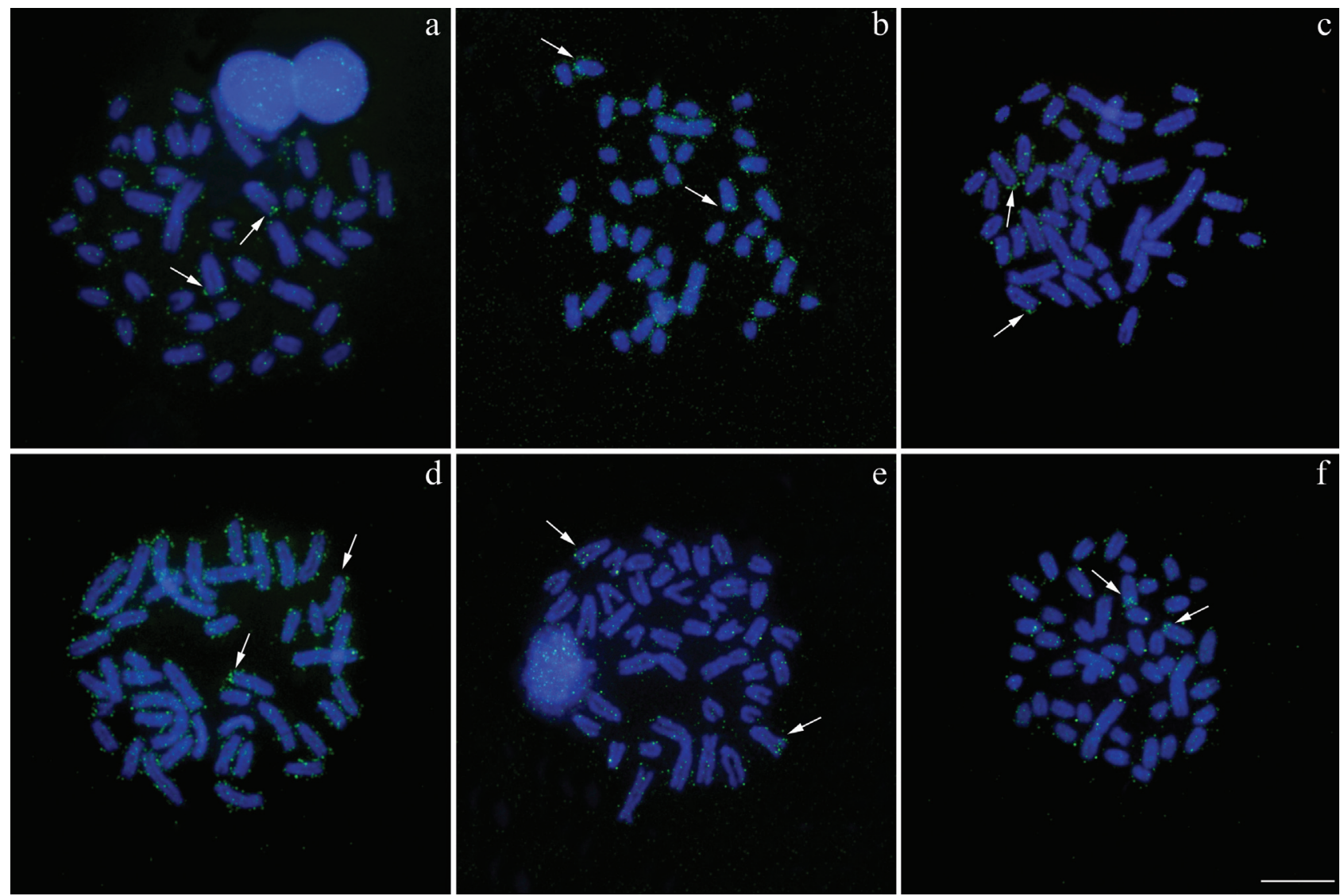

Figure 2 - Metaphases after FISH treatment using probes of H3 and H4 histone sequences, respectively, in karyomorphs A (a, d), B (b, e), and E (c, f). Arrows indicate the histone site clustering in the acrocentric pair. Bar $=10 \mu \mathrm{m}$. 

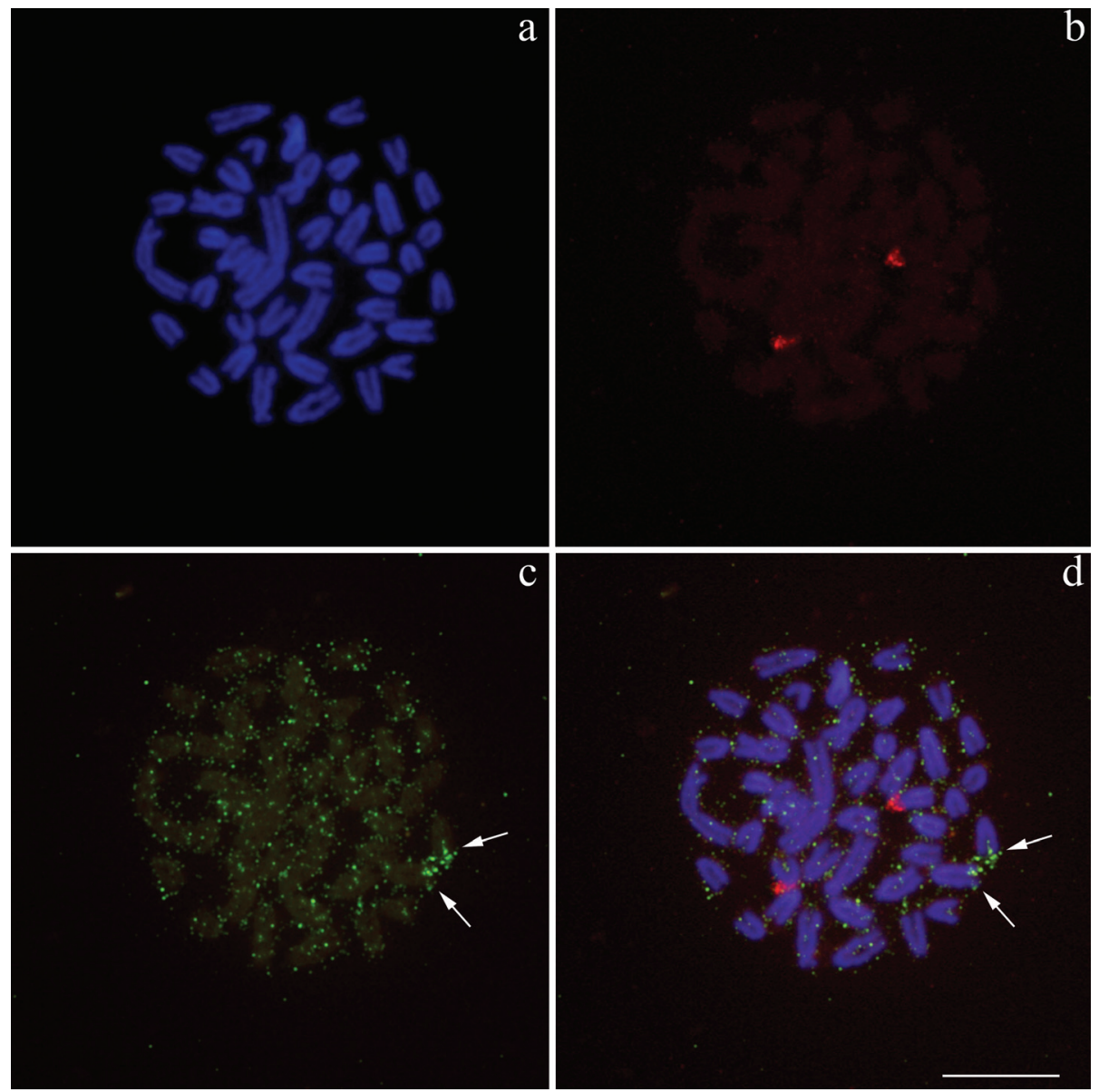

Figure 3 - Karyomorph A metaphase (a) evidencing the 18S rDNA (b) and H3 histone gene (c) hybridization patterns; (d) DAPI-stained metaphase with overlapping images of the $18 \mathrm{~S}$ rDNA and $\mathrm{H} 3$ histone gene. Arrows indicate the histone site clustering in the acrocentric pair. Bar $=10 \mu \mathrm{m}$.

organized into tandemly repeated copies, while in others these sequences may be dispersed throughout the genome in small groups of copies (reviewed in Rooney et al., 2002).

In fish species, data about chromosomal location of histone sequences are restricted to eight species mapped for H1 genes (Pendás et al., 1994; Hashimoto et al., 2011, 2013; Lima-Filho et al., 2012) and only five species with mapped H3 sites (Pansonato-Alves et al., 2013a, 2013b; Silva et al., 2013), all of them presenting histone sequences as conspicuous blocks in chromosomes. Despite the restricted sampling, these studies revealed some particular characteristics, such as differential dispersion of sites and association with $5 \mathrm{~S}$ or $18 \mathrm{~S}$ rDNA (Hashimoto et al., 2011, 2013; Lima-Filho et al., 2012; Pansonato-Alves et al., 2013a, 2013b). More recent studies also showed that H1, $\mathrm{H} 3$ and $\mathrm{H} 4$ histone genes are clustered at the same site in fishes of genus Astyanax (Pansonato-Alves et al., 2013b; Silva et al., 2013). Our present results show that $\mathrm{H} 3$ and $\mathrm{H} 4$ histone sequences appear to be linked to one another and that in Synbranchus their dispersion occurs in small clusters throughout the genome. Moreover, in some acrocentric chromosome pairs there may be a small accumulation of these sites, which may be considered the major histone clusters, characterizing a distinct mode of organization of these sequences in fish chromosomes.

To date, the mapped sites of histone sequences in fishes of distinct orders such as Characiformes (Hashimoto et al., 2011, Pansonato-Alves et al., 2013a), Siluriformes (Hashimoto et al., 2013; Pansonato-Alves et al., 2013a) and Perciformes (Lima-Filho et al., 2012) are shown as large chromosomal blocks. The distinct organization and distribution of the $\mathrm{H} 3$ and $\mathrm{H} 4$ histone sites in $S$. marmoratus lead to the conclusion that, in this group, these sites are organised in small and abundant repetitions throughout the genome. This extensive distribution may be attributed to one of the following factors: $(i)$ extensive occurrence of orphon genes derived from in-tandem repetitive families in eukaryotes, as already demonstrated for histone and ribosomal genes (Childs et al., 1981; Eirín-López et al., 2004) and likely to be related to a birth-and-death evolutionary mechanism (Eirín-López et al., 2004); or (ii) associations between histone sequences and transposable elements (TEs) due to the similarity of their distribution patterns mapped in fishes (Ferreira et al., 2011a, 2011b).

Just as for histone sites, the physical mapping of TEs in representatives of the Neotropical ichthyofauna is re- 

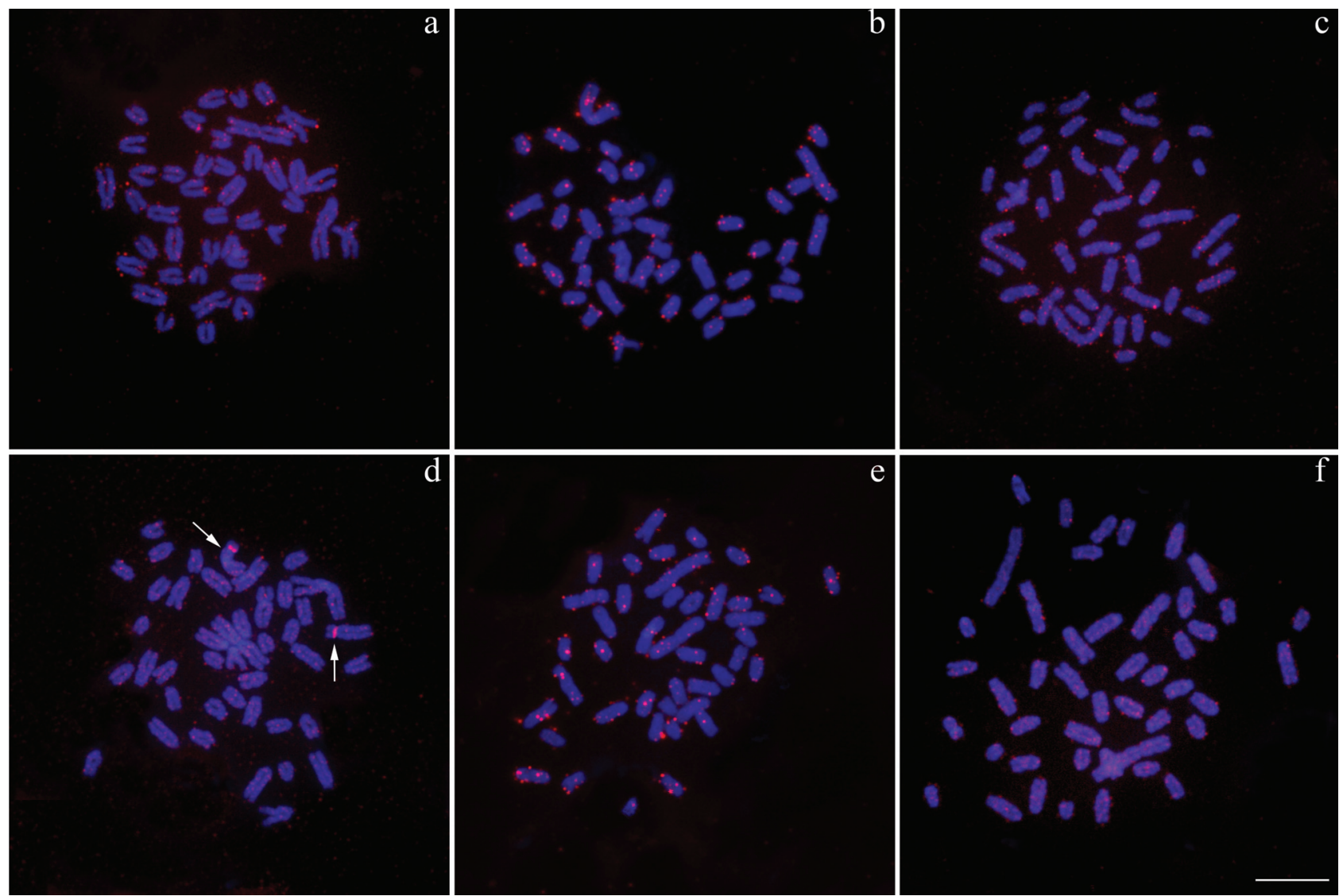

Figure 4 - Metaphases after FISH treatment using Rex 1 and Rex3 probes, respectively, in karyomorphs A (a, d), B (b, e), and E (c, f). Arrows indicate the clustering of Rex3 sites in the centromere of a submetacentric pair. Bar $=10 \mu \mathrm{m}$.

stricted to a small number of species and to the non-LTR retrotransposons Rex1, Rex3 and Rex6 (Gross et al., 2009; Cioffi et al., 2010; Valente et al., 2011; Ferreira et al., 2011a,b; Pansonato-Alves et al., 2013a). The overlap of signals generated by FISH among TEs and other repetitive sequences raises questions about their role in the dispersion of repetitive DNA sequences (Mandrioli et al., 2001; Mandrioli and Manicardi, 2001; Cioffi et al., 2010). In S. marmoratus, the Rex 1 and Rex3 elements are found in small clusters dispersed over all chromosomes. Notably, an accentuated accumulation of repetitions in the centromeric region of pair 3 was found in samples from Bataguassu (karyomorph A); however, this seems to be only a local amplification because the individuals of karyomorph $\mathrm{B}$, which is believed to be recently derived from karyomorph A (unpublished data), did not present such blocks in this chromosome pair.

It is further worth noting that these elements may present variable modes of chromosomal distribution in different species, but tend to be distributed in a similar manner in close groups. The Rex 1, Rex 3 and $\operatorname{Rex} 6$ elements, for example, are primarily compartmentalized in the pericentromeric heterochromatic regions in Cichlid fishes (Teixeira et al., 2009; Valente et al., 2011) and dispersed throughout the genome in Loricariidae, Bathydraconidae and Artedi- draconidae species (Ozouf-Costaz et al., 2004; Ferreira et al., 2011a; Pansonato-Alves et al., 2013a). However, in Characiform species, Rex3 elements may also be compartmentalized (Cioffi et al., 2010; Pansonato-Alves et al., 2013b; Silva et al., 2013), indicating that those elements are highly dynamic and their type of genomic organization does not reflect phylogenetic relationships among species.

Although S. marmoratus presents a remarkable variation in karyotype macrostructure, the physical mapping of histone sequences and transposable elements revealed that these sequences are all dispersed in different karyomorphs, and this seems to be a conserved feature. Thus, we stress the importance of further studies regarding the physical mapping of $\mathrm{H} 1, \mathrm{H} 3$ and $\mathrm{H} 4$ histone genes and other repetitive DNAs, which may be useful in determining the organization of these genes in eukaryote genomes. Similarly, the mapping of transposable elements can bring new perspectives on the genomic organization, dispersion of genes and speciation driven by those sequences.

\section{Acknowledgments}

This study was supported by grants from the Brazilian agencies Conselho Nacional de Desenvolvimento Científico e Tecnológico (CNPq) and Fundação de Amparo à 
Pesquisa do Estado de São Paulo (FAPESP). Ricardo Utsunomia had a scholarship from FAPESP (2011/01370-0)

\section{References}

Charlesworth B, Snlegowski P and Stephan W (1994) The evolutionary dynamics of repetitive DNA in eukaryotes. Nature 371:215-220.

Childs G, Maxson R, Cohn RH and Kedes L (1981) Orphons: Dispersed genetic elements derived from tandem repetitive genes of eukaryotes. Cell 23:651-663.

Cioffi MB, Martins C and Bertollo LAC (2010) Chromosome spreading of associated transposable elements and ribosomal DNA in the fish Erythrinus erythrinus. Implications for genome change and karyoevolution in fish. BMC Evol Biol 10:271-280.

Colgan DJ, McLauchlan A and Wilson GDF (1998) Histone H3 and U2 snRNA DNA sequences and arthropod molecular evolution. Aust J Zool 46:419-437.

Eirin-Lopez JM, González-Tizón AM, Martínez A and Méndez J (2004) Birth-and-death evolution with strong purifying selection in the Histone $\mathrm{H} 1$ multigene family and the origin of orphon H1 genes. Mol Biol Evol 21:1992-2003.

Ferreira DC, Oliveira C and Foresti F (2011a) Elements Rex1 and Rex3 in three fish species in the subfamily Hypoptopomatinae (Teleostei, Siluriformes, Loricariidae). Cytogenet Genome Res 132:64-70.

Ferreira DC, Oliveira C and Foresti F (2011b) A new dispersed element in the genome of the catfish Hisonotus leucofrenatus (Teleostei, Siluriformes, Hypoptopomatinae). Mob Genet Elements 1:103-106.

Foresti F, Almeida-Toledo LF and Toledo-Filho SA (1981) Polymorphic nature of nucleolus organizer regions on fishes. Cytogenet Cell Gen 31:137-144.

Foresti F, Oliveira C and Tien OS (1992) Cytogenetic studies of the genus Synbranchus (Pisces, Synbranchiformes, Synbranchidae). Naturalia 17:129-138.

Gross MC, Schneider CH, Valente GT, Porto JIR, Martins C and Feldberg E (2009) Comparative cytogenetic analysis of the genus Symphysodon (Discus fishes, Cichlidae): Chromosomal characteristics of retrotransposons and minor ribosomal DNA. Cytogenet Genome Res 127:43-53.

Gursel I, Gursel M, Yamada H, Ishii KJ, Takeshita F and Klinman DM (2003) Repetitive elements in mammalian telomeres suppress bacterial DNA-induced immune activation. J Immunol 171:1393-1400.

Haff T, Schmid M, Steinlein C, Galetti Jr PM, Willard H (1993) Organization and molecular cytogenetics of a satellite DNA family from Hoplias malabaricus (Pisces, Erythrinidae). Chromosome Res 1:77-86.

Hashimoto DT, Ferguson-Smith MA, Rens W, Foresti F and Porto-Foresti F (2011) Chromosome mapping of H1 histone and 5S rRNA genes clusters in three species of Astyanax (Teleostei, Characiformes). Cytogen Genome Res 134:6471.

Hashimoto DT, Ferguson-Smith MA, Rens W, Prado FD, Foresti F and Porto-Foresti F (2013) Cytogenetic mapping of H1 histone and ribosomal RNA genes in hybrids between catfish species Pseudoplatystoma corruscans and Pseudoplatystoma reticulatum. Cytogen Genome Res 139:102-106.
Kedes LH (1979) Histone genes and histone messengers. Annu Rev Biochem 48:837-870.

Lima-Filho PA, Cioffi MB, Bertollo LAC and Molina WF (2012) Chromosomal and morphological divergences in Atlantic populations of the frillfin Bathygobius soporator (Gobiidae, Perciformes). J Exp Mar Biol Ecol 434:63-70.

Mandrioli M, Manicardi GC, Machella N and Caputo V (2001) Molecular and cytogenetic analysis of the goby Gobius niger (Teleostei, Gobiidae). Genetica 110:73-78.

Mandrioli M and Manicardi GC (2001) Cytogenetics and molecular analysis of the pufferfish Tetraodon fluviatilis (Osteichthyes). Genetica 111:433-438.

Martins C and Galetti Jr PM (1999) Chromosomal localization of 5S rDNA genes in Leporinus fish (Anostomidae, Characiformes). Chromosome Res 7:363-367.

Melilo IFM, Foresti F and Oliveira C (1996) Additional cytogenetic studies on local populations of Synbranchus marmoratus (Pisces, Synbranchiformes, Synbranchidae). Naturalia 21:201-208.

Nagoda N, Fukuda A, Nakashima Y and Matsuo Y (2005) Molecular characterization and evolution of the repeating units of histone genes in Drosophila americana: Coexistence of quartet and quintet units in a genome. Insect Mol Biol 14:713-717.

Ozouf-Costaz C, Brandt J, Korting C, Pisano E, Bonillo C, Coutanceau JP and Volff JN (2004) Genome dynamics and chromosomal localization of the non-LTR retrotransposons Rex1 and Rex3 in Antartic fish. Antartic Science 16:51-57.

Pansonato-Alves JC, Serrano EA, Utsunomia R, Scacchetti PC, Oliveira C and Foresti F (2013a) Mapping five repetitive DNA classes in sympatric species of Hypostomus (Teleostei, Siluriformes, Loricariidae): Analysis of chromosomal variability. Rev Fish Biol Fisher 23:477-489

Pansonato-Alves JC, Hilsdorf AWS, Utsunomia R, Silva DMZA, Oliveira C and Foresti F (2013b) Chromosomal mapping of repetitive DNA and cytochrome $\mathrm{C}$ oxidase I sequence analysis reveal differentiation among sympatric samples of Astyanax fasciatus (Characiformes, Characidae). Cytogenet Genome Res 141:133-142.

Pendás AM, Morán P and García-Vázquez E (1994) Organization and chromosomal location of the major histone cluster in brown trout, Atlantic salmon and rainbow trout. Chromosoma 103:147-152.

Pineau P, Henry M, Suspène R, Marchio A, Dettai A, Debruyne R, Petit T, Lécu A, Moisson P, Dejean A, et al. (2005) A universal primer set for PCR amplification of nuclear histone H4 genes from all animal species. Mol Biol Evol 22:582588.

Pinkel D, Straume T and Gray JW (1986) Cytogenetic analysis using quantitative, high-sensitivity, fluorescence hybridization. Proc Natl Acad Sci USA 83:2934-2938.

Sanchez S and Fenocchio AS (1996) Karyotypic analysis in three populations of the South-American eel like fish Synbranchus marmoratus. Caryologia 49:65-71.

Silva DMZA, Pansonato-Alves JC, Utsunomia R, Daniel SN, Hashimoto DT, Oliveira C, Porto-Foresti F and Foresti F (2013) Chromosomal organization of repetitive DNA sequences in Astyanax bockmanni (Teleostei, Characiformes): Dispersive location, association and co-localization in the genome. Genetica 141:329-336. 
Sumner AT (2003) Chromosomes: Organization and Function. Blackwell Publishing Company, London, 287 pp.

Teixeira WG, Ferreira IA, Cabral-de-Melo DC, Mazzuchelli J, Valente GT, Pinhal D, Poletto AB, Venere PC and Martins C (2009) Organization of repeated DNA elements in the genome of the cichlid fish Cichla kelberi and its contributions to the knowledge of fish genomes. Cytogenet Genome Res 125:224-234.

Torres RA, Roper JJ, Foresti F and Oliveira C (2005) Surprising genomic diversity in the Neotropical Fish Synbranchus marmoratus (Teleostei, Synbranchidae): How many species? Neotrop Ichthyol 3:277-284.

Valente GT, Mazzuchelli J, Ferreira IA, Poletto AB, Fantinatti BEA and Martins C (2011) Cytogenetic Mapping of the retroelements Rex1, Rex3 and Rex6 among cichlid fish: New insights on the chromosomal distribution of transposable elements. Cytogenet Genome Res 133:34-42.

Vicari MR, Nogaroto V, Noleto RB, Cestari MM, Cioffi MB, Almeida MC, Moreira-Filho O and Artoni RF (2010) Satel- lite DNA and chromosomes in Neotropical fishes: Methods, applications and perspectives. J Fish Biol 76:1094-1116.

Volff JN, Körting C, Sweeney K and Schartl M (1999) The non-LTR retrotransposon Rex3 from the fish Xiphophorus is widespread among teleosts. Mol Biol Evol 16:1427-1438.

Volff JN, Körting C and Schartl M (2000) Multiple lineages of the non-LTR retrotransposon Rexl with varying success in invading fish genomes. Mol Biol Evol 17:1673-1684.

Wagner RP, Maguire MP and Stallings RL (1993) Chromosomes: A synthesis. Wiley-Liss Inc., New York pp. 523.

White TJ, Bruns T, Lee S and Taylor J (1990) Amplification and direct sequencing of fungal ribosomal RNA genes for phylogenetics. In: Innis MA, Gelfand DH, Sninsky JJ and White TJ (eds) PCR Protocols: A Guide to Methods and Applications. Academic Press Inc., New York, pp 315-322.

Associate Editor: Igor Schneider

All the content of the journal, except where otherwise noted, is licensed under a Creative Commons License CC BY-NC. 